\title{
ENXERTO ÓSSEO AUTÓGENO DE RAMO MANDIBULAR: RELATO DE CASO
}

Bruna FORTES FONTES, Aline Monise SEBASTIANI, Ricardo PASQUINI FILHO

Os enxertos ósseos autógenos em bloco de origem bucal são indicados para os pacientes com interesse de reabilitação com implantes osseointegrados, que se apresentam com insuficiência óssea do processo alveolar em uma área desdentada unitária ou parcial (TRYPLETT E SHOW, 1998). Paciente de 45 anos de idade com prótese fixa mal adaptada na região de incisivo central do lado direito e com enxerto de material aloplástico nãoosseointegrador na região. A conduta foi remoção daquele material, realização de cirurgia de enxerto ósseo autógeno, para conseguir condições adequadas para reabilitação com prótese sobre implante. O enxerto ósseo foi removido do ramo mandibular, o sítio receptor foi preparado na tábua óssea vestibular realizando-se uma pequena caixa para receber o enxerto, e com perfurações feitas com broca esférica para aumentar a perfusão sanguínea, facilitando a integração e substituição óssea. $O$ enxerto foi fixado com um parafuso de titânio. Foi utilizado osso liofilizado de origem bovina (Bio-Oss) para preenchimento de pequenos espaços entre o enxerto e a área receptora. Toda área do enxerto ósseo foi coberta com uma membrana (Bio-Gide) para evitar a migração das células do tecido conjuntivo para o espaço. Cinco meses depois, o osso encontrava-se em excelentes condições para instalação do implante.

Palavras-chave: implante dentário; enxerto ósseo; cirurgia ambulatorial 